\title{
A Comparison of Methods for Assessing Groundwater Flooding Due to Sea Level Rise
}

\author{
Daniel J. Rozell \\ Department of Technology and Society, Stony Brook University, USA \\ daniel.rozell@ @stonybrook.edu
}

19 January 2022

This paper is a non-peer reviewed preprint submitted to EarthArXiv.

\begin{abstract}
:
This technical note compares two groundwater flooding assessments for a site on the Rockaway Peninsula of New York City, a coastal barrier island subject to several climate change risks including groundwater flooding. One assessment was performed using a MODFLOW groundwater model while the other used an interpolated water table map constructed in GIS. The two methods showed minor differences in estimates for the current position of the water table. Likewise, the position of the water table later in this century due to $0.75 \mathrm{~m}$ of sea level rise indicated similar groundwater levels as well as similar patterns of emergent wetlands. Both methods yielded the same insight that widespread groundwater emergence is expected in the study area within the next 50 years. This suggests that for settings with similar topology and hydrogeological conditions, such as sandy barrier islands and low-lying coastal plains, simple water table mapping techniques are a reasonable alternative groundwater flooding assessment tool comparable to full groundwater models which can be time-consuming and expensive to create.
\end{abstract}

Key Words: climate change, groundwater flooding, sea level rise, water table map

Highlight: Groundwater flooding due to sea level rise on barrier islands may be assessed using water table maps rather than full groundwater models 


\section{INTRODUCTION}

Given the importance of groundwater as an irrigation and potable water source, projections of widespread aquifer depletion exacerbated by climate change have become a major focus of groundwater research (Famiglietti, 2014; Rodell et al., 2018; Jasechko and Perrone, 2021). However, with over half a billion people living in coastal zones less than $10 \mathrm{~m}$ above sea level (McMichael et al., 2020), many also face the opposite challenge of a future world with too much groundwater beneath them as coastal water tables rise in conjunction with sea level rise (SLR). Only a decade ago, major reviews of climate change impacts on groundwater made scant mention of potential coastal groundwater flooding (Green et al., 2011; Taylor et al., 2013). More recent reviews (Maliva, 2021) recognize SLR-induced groundwater flooding as an important coastal threat that should be included along with tidal flooding and storm surge in coastal urban planning analyses.

Because rising groundwater comes from below, it results in distinct damages compared to direct marine inundation (Habel et al., 2020). These damages include basement flooding, buried infrastructure flooding and corrosion, decreased sewer capacities (Fung and Babcock, 2020), soil contaminant remobilization, soil instability, and wetland creation. These effects are generally expected within a kilometer from the shore but can extend tens of kilometers in low-lying deltas (Hay and Mimura, 2005).

Various methods have been proposed for assessing SLR-induced groundwater flooding (Rozell, 2020). Because the extent of groundwater emergence is dependent on local conditions, detailed groundwater models have been used to characterize potential local groundwater flooding (Bjerklie et al., 2012; Walter et al., 2016; Habel et al., 2017; Knott et al., 2018; Befus et al., 2020). However, such models can be time-consuming and expensive to create and calibrate. Simplified methods that only attempt to model the water table and estimate its movement have been recommended as an initial groundwater flood risk assessment method (Plane et al., 2019). This case study compares a full groundwater model with a water table elevation map (WTEM) and discusses the applicability of the two approaches.

\section{CASE STUDY: GATEWATE NATIONAL RECREATION AREA}

A study of potential groundwater emergence from SLR in the Rockaway Peninsula of New York City, which includes parts of Gateway National Recreation Area (Figure 1), was conducted using both a MODFLOW (Harbaugh, 2005) groundwater model and a WTEM. For the study, sea level rise estimates were based on a New York City Panel on Climate Change Report (2015).

Likewise, for both models, the elevation of the area was modeled using a 2017 New York City LiDAR topo-bathymetric hydro-enforced unfilled digital elevation model (DEM) — a bare earth model with all vegetation and anthropogenic features removed (Quantum Spatial, 2018). The 
DEM had an estimated $0.07 \mathrm{~m}$ vertical accuracy (referenced to NAVD88 vertical datum) and $0.30 \mathrm{~m}$ horizontal resolution (referenced to NAD83 horizontal datum).



Figure 1: Rockaway Peninsula in New York City

\section{MODFLOW MODEL}

The MODFLOW groundwater model was constructed with the following considerations.

\section{Hydrogeologic Conditions}

An unpublished geotechnical investigation performed for the City of New York conducted in 2016 found that the soil in the Gateway National Recreation Area of Rockaway Peninsula consisted primarily of fine- to medium-grained sand with traces of silt. A few samples deeper than $15 \mathrm{~m}$ below ground surface were more than $10 \%$ silt. Permeability testing determined the in-situ permeability to be approximately $30 \mathrm{~m} /$ day. These findings agreed with a previous USGS report detailing the hydrogeology of the area (Buxton and Shernoff, 1999). According to the USGS, bedrock depth in the study area is approximately $275 \mathrm{~m}$ below sea level, but the uppermost confining layer - the Gardiners Clay_is about $45 \mathrm{~m}$ below sea level. Since most groundwater flow will occur above that confining layer, the model bottom was set to $45 \mathrm{~m}$ below sea level. 
For this study, the groundwater model was created with three layers. From top to bottom, the layer bottoms were set at 7-m, 22-m, and 45-m below sea level, respectively. An initial hydraulic conductivity of $30 \mathrm{~m} /$ day was used for all layers but was adjusted during calibration. A 10:1 ratio of horizontal to vertical hydraulic conductivities was assumed for the barrier island deposits (Bokuniewicz and Pavlik, 1990).

\section{Recharge}

The modeled rate of groundwater recharge was determined from a USGS report (Reitz et al., 2017) estimating recharge, quick-flow runoff, and evapotranspiration components of precipitation for the US for years 2000-2013. The study area's effective recharge value of 0.64 $\mathrm{m} /$ year reflects the portion of precipitation available to replenish the groundwater table after accounting for runoff and evapotranspiration but ignoring any anthropogenic withdrawal or addition of groundwater.

In addition, water usage records for communities in the study area showed an annual usage of approximately $325,000 \mathrm{~m}^{3}$ of public water from New York City. Because this water originates from inland New York and the study area has no sewers, this water constituted an additional local recharge to groundwater. Using an evapotranspiration rate of $50 \%$, typical for the region (Peterson, 1987), the additional recharge was spread evenly over areas with structures resulting in an effective recharge of $0.76 \mathrm{~m} /$ year for those areas.

\section{Coastal Effects}

The average tide was determined from the closest NOAA tide station in Sandy Hook, NJ approximately $11 \mathrm{~km}$ from the study area. Because summer tides tend to run higher than average due to seasonal changes in temperature, precipitation, wind patterns, etc., the average sea level was about $0.15 \mathrm{~m}$ NAVD88. However, the elevation of the water table at the coast was set higher than mean sea level due to known tidal and wave effects on coastal groundwater (e.g., Nielsen, 1990, 1999; Turner et al., 1997; Li and Jiao, 2003). Plane et al. (2019) used a 0.3-m offset at the coast to account for these phenomena. The model calibration and history-matching process confirmed the appropriateness of this offset for the Rockaway Peninsula.

\section{Groundwater Monitoring}

Groundwater data was collected from a total of 10 monitoring wells, each installed to a maximum depth of $5 \mathrm{~m}$ below ground surface with $3 \mathrm{~m}$ of screened casing and $2 \mathrm{~m}$ of solid riser casing ending in a cap to prevent infiltration of rain and tampering. Installed pressure transducers measured groundwater levels for approximately 3 months in the summer of 2019. The diurnal tidal signal could be seen in all well data. Near-shore wells experienced daily tidal water table 
movements of up to $0.3 \mathrm{~m}$ while large water table movements of inland wells were primarily due to precipitation.

\section{MODEL RESULTS}

The subsequent MODFLOW groundwater model was calibrated using two months of averaged water elevation data. An additional month of data was used for history-matching. The model was then used to create a map of depth to groundwater for both current conditions and a simulated future scenario with $0.75 \mathrm{~m}$ of sea level rise (Figure 2). The current conditions map shows that the only open water exists at the western end of Rockaway Peninsula. This corresponds quite closely with current aerial imagery suggesting that the model is a realistic approximation of the local water table.

\section{WATER TABLE ELEVATION MAP}

The WTEM was created using the same well observation and tidal data as the full groundwater model, but without the need to estimate long-term precipitation and recharge rates or hydraulic conductivities. Consistent with previous WTEM approaches (Hoover et al., 2017; Hummel et al., 2018; Plane et al., 2019), a water table surface was constructed by interpolating between averaged well points and additional reference points at the shoreline representing the known position of the water table. As with the full groundwater model, the same offset of $0.3 \mathrm{~m}$ was used to account for the discontinuity between the shoreline water table and the mean tide elevation. SLR effects were approximated with a linear rise of water table.

While there are no notable lakes or streams on the Rockaway Peninsula, any natural inland water bodies that are likely to intersect the water table (Winter, 1999) can also be set as known water table points. These points can serve to fill in spatial data gaps not sufficiently covered by the groundwater monitoring wells or shoreline reference points. This technique has been used to map the coastal aquifer in Delaware (Martin and Andres, 2008). Alternatively, these points can be used to assess the validity of the generated modeled water table surface.

The water table surface was generated using a thin plate spline interpolation within a triangulated irregular network. Spline interpolations, or similar radial basis functions, are useful methods for water table surface generation with a small dataset because they can generate a smooth surface that goes through all data points and can exceed the maximum data point so that it is not necessary to measure the highest point in the water table.

A depth to groundwater map was created by subtracting the resulting water table surface from a DEM as seen in Figure . An additional depth to groundwater map was generated that accounted for the $0.75 \mathrm{~m}$ of sea level rise considered in this study. 

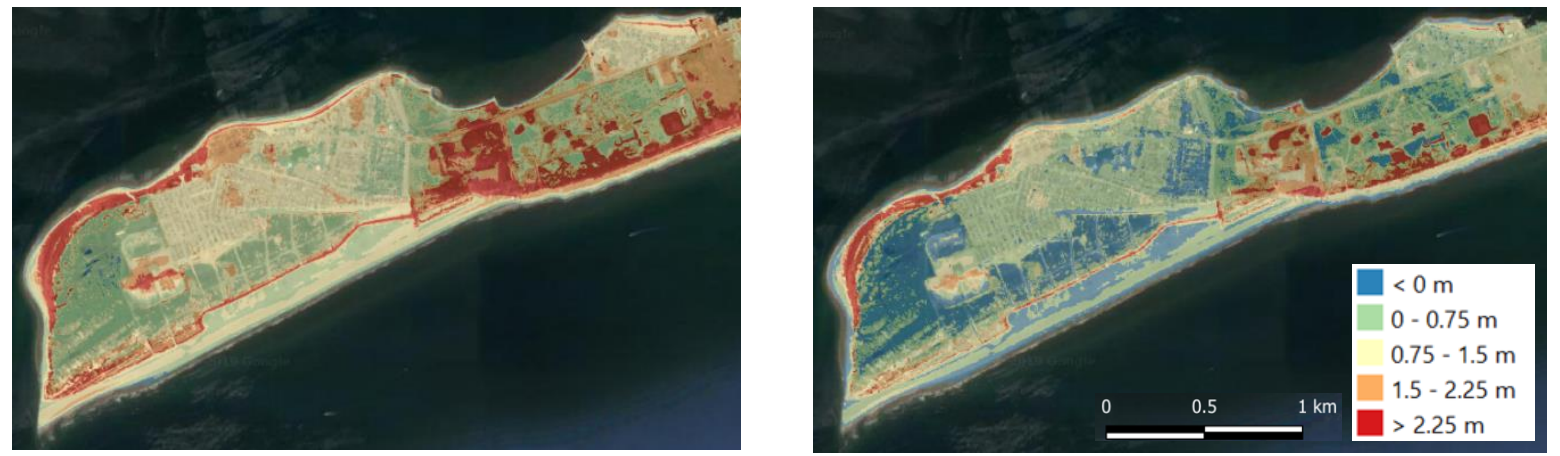

Figure 2: Depth to groundwater map generated by MODFLOW groundwater model for current conditions (left) and $0.75 \mathrm{~m}$ of SLR (right)
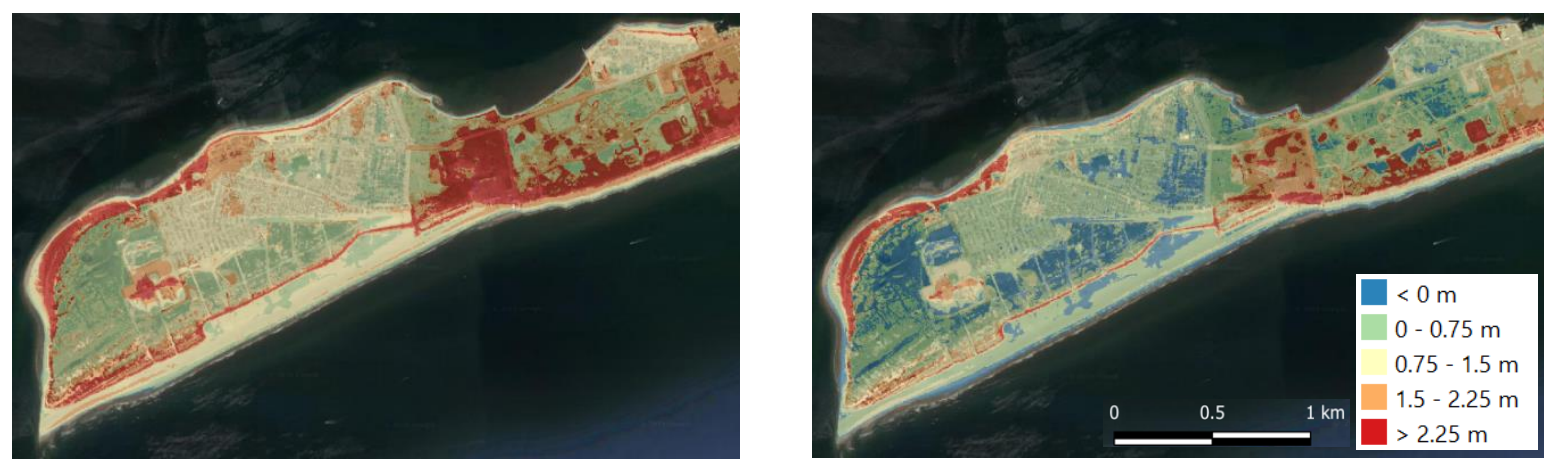

Figure 3: Depth to groundwater map generated by WTEM for current conditions (left) and $0.75 \mathrm{~m}$ of SLR (right)

\section{DISCUSSION}

The depth-to-groundwater maps generated by the groundwater model and WTEM show some minor differences, less than $0.5-\mathrm{m}$ vertical variation at any point, for current conditions and slightly more divergence for the future SLR scenario. However, given the considerable uncertainty in SLR projections, the differences between the two methods are probably not the largest source of map uncertainty. In the case of Rockaway Peninsula, the MODFLOW model and WTEM provide sufficiently similar information. In this case, both methods provide the same insight that Rockaway Peninsula is likely to experience widespread groundwater emergence in the next 50 years and that the ephemeral and stable wetlands of this area will likely grow over time.

One caveat in this comparison is that the MODFLOW model did not account for surface flow of emergent groundwater which is typically done with the Drain (DRN) package in MODFLOW. Areas with topography-limiting conditions are expected to have less water table rise as emergent groundwater rapidly drains away in the form of surface water (Befus et al., 2020). Failing to account for emergent groundwater drainage should cause the groundwater model results to yield 
similar over-estimations of groundwater rise as a WTEM. However, in the case of the Rockaway Peninsula, there are no streams and no stormwater management systems for any structures in the area despite dunes along most of the shoreline. Present-day occurrences of emergent groundwater after heavy rains tend to cause temporary ponding that slowly recedes as the water table returns to equilibrium. That is, temporary emergent groundwater currently tends to recharge near its location of emergence and no drainage occurs (although evaporation rates are presumably higher). This simplification of ignoring surface flow was appropriate due to the unique soil conditions of study site. The area is a barrier island comprised almost entirely of sand deposited within the last century after the Breezy Point jetty was constructed in 1935 to prevent sand from accumulating in the mouth of New York Harbor. In the future, when groundwater emergence is permanent, the affected areas will either become wetlands, or drainage channels to the coast will be installed requiring updated modeling to describe the surface water flow.

It should also be noted that water tables vary depending on many factors including tides, seasons, droughts, heavy precipitation, or groundwater pumping. While the near-shore water table is more tidally influenced, it is ultimately constrained by mean sea level and tends to be relatively stable compared to further inland which responds more strongly to changes in precipitation or pumping. For the Rockaway Peninsula case study, the full groundwater model and simplified water table elevation map yielded similar results. Presumably, these results can be extended to similar hydrogeological settings. That is, sandy barrier islands and low-lying coastal plains will likely obtain equivalent analysis outcomes using either method.

However, the author's experience in other areas suggests that there are limits to the equivalency of the two methods. For example, areas with steep gradients and irregular topography, such as coastal bluffs, can be challenging to model using the WTEM method. In general, water tables tend to mimic surface topography. As a result, a sparce distribution of inland wells or surface water features can result in a smoothed interpolated water table surface that misses small topographical features resulting in overestimations and underestimations where the terrain has rapid gradient changes. For example, interpolation methods will generally underestimate water table gradient changes at bluffs and steep riverbanks. In such cases, groundwater models will yield more realistic results. Likewise, complex hydrogeological features, such as perched water tables or artesian wells in confined aquifers, can make the coastal water table appear more variable than it is in reality. Local geological knowledge and professional judgement can help avoid such errors.

Conversely, a WTEM may offer a more appropriate representation of the local water table in urbanized areas. The combination of randomly disturbed soils, impervious surfaces, and complex stormwater drainage systems can make aquifer recharge and hydraulic conductivity so heterogeneous that it precludes the creation of a detailed and representative groundwater model within a reasonable budget. In such cases, a methodology proposed by Rahimi et al. (2020) may 
be more appropriate. That is, using a WTEM coupled with a stormwater model will yield more useful results in urban settings - especially for characterizing potential groundwater flooding conditions during and after rain events. An elevated water table reduces the vadose zone and hence the ground's ability to store stormwater. Because emergent groundwater flooding is most likely to happen during major rain events, concurrent consideration of stormwater and groundwater flooding models has considerable value.

Further study is required to determine how equivalent these methods are under a range of coastal scenarios. However, this case study serves as a demonstration that both methods provide similar results on a barrier island. Thus, a GIS-generated water table map appears to be a viable alternative assessment tool for a large number of vulnerable coastal communities. This is a valuable confirmation that could save considerable time and effort in coastal climate risk assessments.

\section{ACKNOWLEDGEMENTS}

The work was supported by Arcadis U.S., Inc. and stems from a project funded by the City of New York through a federal disaster recovery grant (FEMA-4085-DR-NY HMGP Project \# 4085-058). The author declares no conflicts of interest. The opinions and errors contained herein are the author's alone.

\section{REFERENCES}

Befus, K.M.; Barnard, P.L.; Hoover, D.J.; Finzi Hart, J.A. and Voss, C.I. 2020. Increasing threat of coastal groundwater hazards from sea-level rise in California. Nature Climate Change 10(10): 946-952, https://doi.org/10.1038/s41558-020-0874-1.

Bjerklie, D.M.; Mullaney, J.R.; Stone, J.R.; Skinner, B.J. and Ramlow, M.A. 2012. Preliminary Investigation of the Effects of Sea-Level Rise on Groundwater Levels in New Haven, Connecticut. Open-File Report 2012-1025. Reston, VA: U.S. Geological Survey, https://pubs.usgs.gov/of/2012/1025/.

Bokuniewicz, H. and Pavlik, B. 1990. Groundwater Seepage along a Barrier Island. Biogeochemistry 10(3): 257-276.

Buxton, H.T. and Shernoff, P.K. 1999. Ground-water resources of Kings and Queens counties, Long Island, New York. USGS Numbered Series 2498. Ground-water resources of Kings and Queens counties, Long Island, New YorkWater Supply Paper 2498. U.S. Geological Survey, https://doi.org/10.3133/wsp2498.

Famiglietti, J.S. 2014. The global groundwater crisis. Nature Climate Change 4(11): 945-948, https://doi.org/10.1038/nclimate2425.

Fung, A. and Babcock, R. 2020. A Flow-Calibrated Method to Project Groundwater Infiltration into Coastal Sewers Affected by Sea Level Rise. Water 12(7): 1934, https://doi.org/10.3390/w12071934.

Green, T.R.; Taniguchi, M.; Kooi, H.; Gurdak, J.J.; Allen, D.M.; Hiscock, K.M.; Treidel, H. and Aureli, A. 2011. Beneath the surface of global change: Impacts of climate change on 
groundwater. Journal of Hydrology 405(3): 532-560,

https://doi.org/10.1016/j.jhydrol.2011.05.002.

Habel, S.; Fletcher, C.H.; Anderson, T.R. and Thompson, P.R. 2020. Sea-Level Rise Induced Multi-Mechanism Flooding and Contribution to Urban Infrastructure Failure. Scientific Reports 10(1): 3796, https://doi.org/10.1038/s41598-020-60762-4.

Habel, S.; Fletcher, C.H.; Rotzoll, K. and El-Kadi, A.I. 2017. Development of a model to simulate groundwater inundation induced by sea-level rise and high tides in Honolulu, Hawaii. Water Research 114: 122-134, https://doi.org/10.1016/j.watres.2017.02.035.

Harbaugh, A.W. 2005. MODFLOW-2005, the U.S. Geological Survey modular ground-water model - the Ground-Water Flow Process. U.S. Geological Survey Techniques and Methods 6-A16. Reston, VA: U.S. Geological Survey.

Hay, J.E. and Mimura, N. 2005. Sea-Level Rise: Implications for Water Resources Management. Mitigation and Adaptation Strategies for Global Change 10(4): 717-737, https://doi.org/10.1007/s11027-005-7305-5.

Hoover, D.J.; Odigie, K.O.; Swarzenski, P.W. and Barnard, P. 2017. Sea-level rise and coastal groundwater inundation and shoaling at select sites in California, USA. Journal of Hydrology: Regional Studies 11: 234-249, https://doi.org/10.1016/j.ejrh.2015.12.055.

Hummel, M.A.; Berry, M.S. and Stacey, M.T. 2018. Sea Level Rise Impacts on Wastewater Treatment Systems Along the U.S. Coasts. Earth's Future 6(4): 622-633, https://doi.org/10.1002/2017EF000805.

Jasechko, S. and Perrone, D. 2021. Global groundwater wells at risk of running dry. Science 372(6540): 418-421, https://doi.org/10.1126/science.abc2755.

Knott, J.F.; Jacobs, J.M.; Daniel, J.S. and Kirshen, P. 2018. Modeling Groundwater Rise Caused by Sea-Level Rise in Coastal New Hampshire. Journal of Coastal Research 35(1): 143157, https://doi.org/10.2112/JCOASTRES-D-17-00153.1.

Li, H. and Jiao, J.J. 2003. Influence of the tide on the mean watertable in an unconfined, anisotropic, inhomogeneous coastal aquifer. Advances in Water Resources 26(1): 9-16, https://doi.org/10.1016/S0309-1708(02)00097-0.

Maliva, R. 2021. Climate Change and Groundwater: Planning and Adaptations for a Changing and Uncertain Future. WSP Methods in Water Resources Evaluation 6. Cham, Switzerland: Springer Nature.

Martin, M.J. and Andres, A.S. 2008. Analysis And Summary Of Water-Table Maps For The Delaware Coastal Plain. Technical Report 73. Report of Investigations. Newark, DE: Delaware Geological Survey, University of Delaware, https://udspace.udel.edu/handle/19716/3173 (accessed 3 May 2021)

McMichael, C.; Dasgupta, S.; Ayeb-Karlsson, S. and Kelman, I. 2020. A review of estimating population exposure to sea-level rise and the relevance for migration. Environmental Research Letters 15(12): 123005, https://doi.org/10.1088/1748-9326/abb398.

New York City Panel on Climate Change. 2015. Report Executive Summary. Annals of the New York Academy of Sciences 1336(1): 9-17, https://doi.org/10.1111/nyas.12591.

Nielsen, P. 1990. Tidal dynamics of the water table in beaches. Water Resources Research 26(9): 2127-2134, https://doi.org/10.1029/WR026i009p02127.

Nielsen, P. 1999. Groundwater Dynamics and Salinity in Coastal Barriers. Journal of Coastal Research 15(3): 732-740.

Peterson, D.S. 1987. Ground-water-recharge rates in Nassau and Suffolk counties, New York. USGS Numbered Series 86-4181. Ground-water-recharge rates in Nassau and Suffolk 
counties, New YorkWater-Resources Investigations Report 86-4181. U.S. Geological Survey, https://doi.org/10.3133/wri864181 (accessed 11 June 2021)

Plane, E.; Hill, K. and May, C. 2019. A Rapid Assessment Method to Identify Potential Groundwater Flooding Hotspots as Sea Levels Rise in Coastal Cities. Water 11(11): 2228, https://doi.org/10.3390/w11112228.

Quantum Spatial. 2018. New York City, New York Topobathymetric LiDAR Technical Data Report. Corvallis, OR: The City of New York -NYC DoITT, https://gis.ny.gov/elevation/NYC-topobathymetric-DEM.htm (accessed 14 June 2021)

Rahimi, R.; Tavakol-Davani, H.; Graves, C.; Gomez, A. and Fazel Valipour, M. 2020. Compound Inundation Impacts of Coastal Climate Change: Sea-Level Rise, Groundwater Rise, and Coastal Precipitation. Water 12(10): 2776, https://doi.org/10.3390/w12102776.

Reitz, M.; Sanford, W.E.; Senay, G. and Cazenas, J. 2017. Annual estimates of recharge, quickflow runoff, and ET for the contiguous U.S. using empirical regression equations. Journal of the American Water Resources Association, https://doi.org/10.1111/17521688.12546.

Rodell, M.; Famiglietti, J.S.; Wiese, D.N.; Reager, J.T.; Beaudoing, H.K.; Landerer, F.W. and Lo, M.-H. 2018. Emerging Trends in Global Freshwater Availability. Nature 557(7707): 651-659, https://doi.org/10.1038/s41586-018-0123-1.

Rozell, D.J. 2020. Coastal Resiliency Groundwater Considerations. Groundwater 58(6): 877881, https://doi.org/10.1111/gwat.13035.

Taylor, R.G.; Scanlon, B.; Döll, P.; Rodell, M.; van Beek, R.; Wada, Y.; Longuevergne, L.; Leblanc, M.; Famiglietti, J.S.; Edmunds, M.; Konikow, L.; Green, T.R.; Chen, J.; Taniguchi, M.; Bierkens, M.F.P.; MacDonald, A.; Fan, Y.; Maxwell, R.M.; Yechieli, Y.; Gurdak, J.J.; Allen, D.M.; Shamsudduha, M.; Hiscock, K.; Yeh, P.J.-F.; Holman, I. and Treidel, H. 2013. Ground water and climate change. Nature Climate Change 3(4): 322329, https://doi.org/10.1038/nclimate1744.

Turner, I.L.; Coates, B.P. and Acworth, R.I. 1997. Tides, Waves and the Super-elevation of Groundwater at the Coast. Journal of Coastal Research 13(1): 46-60.

Walter, D.A.; McCobb, T.D.; Masterson, J.P. and Fienen, M.N. 2016. Potential Effects of SeaLevel Rise on the Depth to Saturated Sediments of the Sagamore and Monomoy Flow Lenses on Cape Cod, Massachusetts. Scientific Investigations Report 2016-5058. Reston, VA: U.S. Geological Survey.

Winter, T.C. 1999. Relation of streams, lakes, and wetlands to groundwater flow systems. Hydrogeology Journal 7(1): 28-45, https://doi.org/10.1007/s100400050178. 